\title{
PHOTODYNAMIC EFFECTIVENESS OF LASER DIODE COMBINED WITH OZONE TO REDUCE STAPHYLICOCCUS AUREUS BIOFILM WITH EXOGENOUS CHLOROPHYLL OF DRACAENA ANGUSTIFOLIA LEAVES
}

\author{
Astuti S.D. ${ }^{1}$, Drantantiyas N.D.G. ${ }^{2}$, Putra A.P. ${ }^{1}$, Puspita P.S. ${ }^{3}$, Syahrom A. ${ }^{4}$, Suhariningsih S. \\ 'Airlangga University, Surabaya, Indonesia \\ 2Sumatera Institute of Technology, Bandar Lampung, Indonesia \\ ${ }^{3}$ Sepuluh Nopember Institute of Technology, Surabaya, Indonesia \\ ${ }^{4}$ Universiti Teknologi Malaysia, Johor Bahru, Malaysia
}

\begin{abstract}
Photodynamic inactivation is an effective treatment that uses light irradiation, photosensitizer and oxygen. The aim of this study was to determine photodynamic effectiveness of laser diode combined with ozone to reduce Staphylococcus aureus biofilm using exogenous chlorophyll (Chlo). The chlorophyll was extracted from leave of Dracaena angustifolia. To determine the antibacterial effect of $S$. aureus biofilm treatments, samples were separated into Chlo, Laser, Chlo+Laser, Ozone, Ozone+Laser, Chlo+Ozone+Laser categories. The data were analyzed using ANOVA test. The result of this study showed that Chlo+Ozone+Laser combine treatment at 20 s exposure of ozone with 4 min of irradiation time lead to $80.26 \%$ reduction of biofilm activity, which was the highest efficacy of all the treatment groups. The combination of laser, chlorophyll and lower ozone concentration increases the effectiveness of photodynamic inactivation.
\end{abstract}

Keywords: antibacterial photodynamic therapy, laser irradiation, ozone, chlorophyll, staphylococcus aureus, biofilm.

For citations: Astuti S.D., Drantantiyas N.D.G., Putra A.P., Puspita P.S., Syahrom A., Suhariningsih S. Photodynamic effectiveness of laser diode combined with ozone to reduce Staphylococcus aureus biofilm with exogenous chlorophyll of Dracaena angustifolia leaves // Biomedical photonics. - 2019. - Vol. 8, No. 2. - P. 4-13. doi: 10.24931/2413-9432-2019-8-2-4-13

ЭФФЕКТИВНОСТЬ ФОТОДИНАМИЧЕСКОГО ВОЗДЕЙСТВИЯ В СОЧЕТАНИИ С ОЗОНОМ И ХЛОРОФИЛЛОМ ИЗ ЛИСТЬЕВ DRАСАЕNA ANGUSTIFOLIA HA БИОПЛЕНКИ STAPHYLICOCCUS AUREUS

\author{
Astuti S.D. ${ }^{1}$, Drantantiyas N.D.G. ${ }^{2}$, Putra A.P. ${ }^{1}$, Puspita P.S. ${ }^{3}$, Syahrom A. ${ }^{4}$, Suhariningsih S. \\ 'Университет Аирланга, Сурабая, Индонезия \\ ${ }^{2}$ Технологический институт Суматры, Бандар-Лампунг, Индонезия \\ ${ }^{3}$ Технологический Институт Сепулух Нопембер, Сурабая, Индонезия \\ ${ }^{4}$ Технологический университет Малайзии, Джохор-Бару, Малайзия
}

\section{Резюме}

Фотодинамическая терапия - эффективный метод инактивации бактериальных биопленок, основанный на сочетании воздействий светового излучения, фотосенсибилизатора и кислорода. Цель данного исследования - определение эффективности лазерного облучения в сочетании с озоном при добавлении экзогенного хлорофилла для инактивации биопленки Staphylococcus aureus (S. aureus). Хлорофилл был извлечен из листьев растения Dracaena angustifolia. В ходе исследования на образцах биопленки S. aureus оценивалась антибактериальная активность каждого фактора в отдельности (лазерное излучение, озон, хлорофилл) и нескольких их сочетаний (хлорофилл + лазерное облучение; озон + лазерное облучение; хлорофилл + озон + лазерное облучение). Полученные данные были проанализированы с использованием теста ANOVA. Анализ результатов исследования показал, что комбинированная обработка озоном в течение 20 с в присутствии хлорофилла с последующим облучением в течение 4 мин снизила активность биопленок на 80,26\%, показав самую высокую эффективность среди всех тестируемых групп. Для повышения эффективности фотодинамической терапии бактериальных биопленок рекомендуется использовать комбинацию лазерного излучения с хлорофиллом и озоном. 
Ключевые слова: антибактериальная фотодинамическая терапия, лазерное облучение, озон, хлорофилл, золотистый стафилококк, биопленка.

Для цитирования: Astuti S.D., Drantantiyas N.D.G., Putra A.P., Puspita P.S., Syahrom A., Suhariningsih S. Photodynamic effectiveness of laser diode combined with ozone to reduce Staphylococcus aureus biofilm with exogenous chlorophyll of Dracaena angustifolia leaves, Biomedical photonics, 2019, vol. 8, no. 2, pp.4-13. doi: 10.24931/2413-9432-2019-8-2-4-13

Контакты: Astuti S.D., email: suryanidyah@fst.unair.ac.id

\section{Introduction}

Biofilms are colonies of bacteria that produce a protective matrix layer called extracellular polymeric substance (EPS) and have higher virulence, resistance, and pathogenic properties [1-2]. Almost all antibiotics fail to control the biofilms [3-4]. In addition, there is a possibility of biofilm having the ability to reduce production of hydrogen peroxide $\left(\mathrm{H}_{2} \mathrm{O}_{2}\right)$ which is a precursor of toxic molecules when DNA-protein synthesis changes [5]. Photodynamic inactivation (PDI) was investigated as an alternative method to reduce biofilms [6].

PDI is a therapy method using light, photosensitizer and oxygen. The PDI mechanism starts from the absorption of light the wavelength of which corresponds to the absorbance of photosensitizer. It can produce reactive oxygen species (ROS) through type I and II photochemical processes [7]. A previous report related of PDI using silver nanoparticles as photosensitizer and laser diode with an output of $450.00 \pm 22.34 \mathrm{~nm}$ and $53.16 \pm 0.01 \mathrm{~mW}$. This combination could decrease the surviving biofilm compared to the laser diode itself by $64.48 \pm 0.07 \%$ against $7.07 \pm 0.23 \%$ at $6.13 \pm 0.002 \mathrm{~J} / \mathrm{cm}^{2}$, respectively [8]

Street et al. reported that biofilm reduction depends on the energy dose of light absorbed by the photosensitizer [9]. One of such photosensitizers is chlorophyll. The advantage of using chlorophyll in PDT is that it is cheap, easy to obtain and has short incubation time [10]. Chlorophyll sensitizers are currently used in targeting cancer cells, microbes and infection [11-13].

The amount of ROS production could be increased by the presence of $\mathrm{H}_{2} \mathrm{O}_{2}$ at the target location during the photochemical process with photosensitizer or ozone delivery. Currently, the amount of ozone needed for treatment is still unclear because each tissue structure has specific properties such as periodontitis in dermatology [14]. Hegge et al. reported that the combination of ozone and PDI provides a high efficacy depending on the ozone concentration [15]. This study aimed to determine photodynamic effectiveness of laser diode combined with ozone to reduce Staphylococcus aureus biofilm using exogenous chlorophyll. The chlorophyll was extracted from Dracaena angustifolia leaves.

\section{Materials and Methods \\ Biofilm and Crystal Violet Assay}

The bacterial strain, S. aureus ATCC 25923 was inoculated from Tryptone Soy Agar (Oxoid, UK) and taken on Tryptone Soy Broth sterile (Oxoid, UK). The culture of bacteria were incubated at $37^{\circ} \mathrm{C}$ until bacterial colonies reached $\sim 10^{8} \mathrm{CFU} / \mathrm{mL}$ or $1.0 \mathrm{McFarland}$ Standard. $100 \mu \mathrm{L}$ of bacteria culture was placed on 96-well microplates and $20 \mu \mathrm{L}$ of $2 \%$ sucrose $(\mathrm{w} / \mathrm{v})$ were added. The samples were shaken at $36 \mathrm{rpm}$ for 4 hours and incubated for 48 hours.

Biofilms were grown on well plate and rinses with Phosphate Buffered Saline (PBS) ( $\mathrm{pH} 7.0)$ three times to remove individual cells. $100 \mu \mathrm{L}$ of $1 \%$ crystal violet were added to the sample and incubated with for 30 minutes. The samples were rinsed and dried for 3 hours. $50 \mu \mathrm{L}$ $33 \% \mathrm{GAA}(\mathrm{w} / \mathrm{v})$ were added to the samples; the Optical Density (OD) value was measured at $595 \mathrm{~nm}$.

\section{Chlorophyll Extraction}

The Chlorophyll (Chlo) was extracted from D. angustifolia leaves. $30 \mathrm{~g}$ of fresh leaves were added to $150 \mathrm{~mL}$ of $96 \%$ acetone and mashed into a pulp. The slice of leaves was filtered, purified, homogenized and precipitated, then put into the freezer at $20^{\circ} \mathrm{C}$ for 24 hours then filtered until it became a yellowish sediment. The stored filtrate was evaporated at $40^{\circ} \mathrm{C} .60 \mathrm{~g}$ of silica gel was added to the filtrate. $8 \mathrm{~g}$ of silica gel and $16 \mathrm{ml}$ of petroleum ether (PE) was then added and stirred homogenously for 5 minutes and then let to rest for 2 hours. The chlorophyll extract was dissolved in diethyl ether, then $5 \mathrm{~g}$ of silica gel was added and dried until a green crystal-like powder was formed. The dry chlorophyll extract was added to petroleum ether until it produced yellow filtrate. Finally, 96\% acetone was added into the mixture until a clear silica gel color was produced. To analyze the characterization of chlorophyll, a thin layer chromatography and UV-Vis spectrophotometry (Bio-Rad) were used [15, 16].

\section{Light Sources Apparatus for light irradiation}

Fig. $1 a$ shows an apparatus set-up of light and ozone source and Fig. $1 b$ - a microcontroller block diagram. 


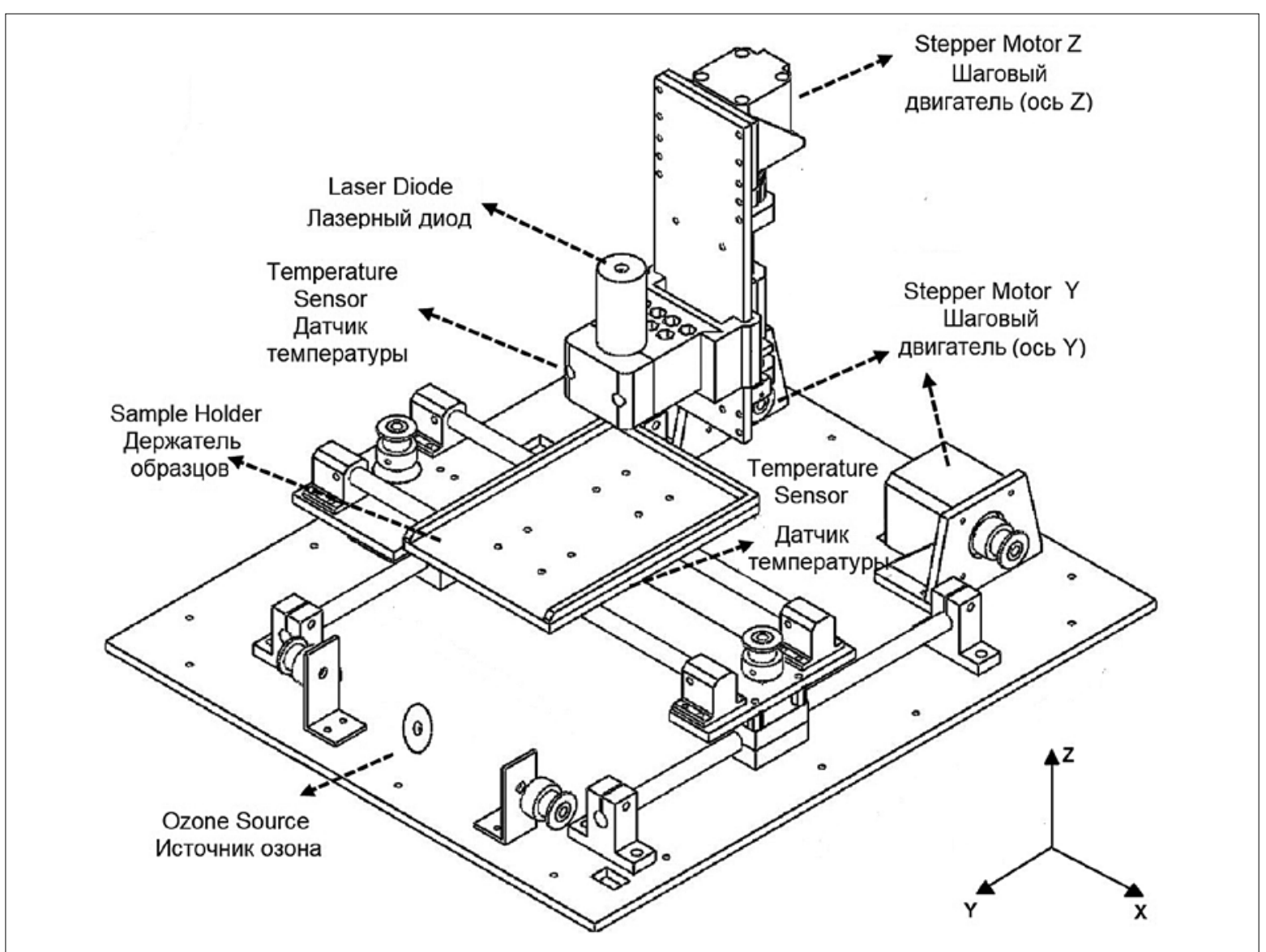

a

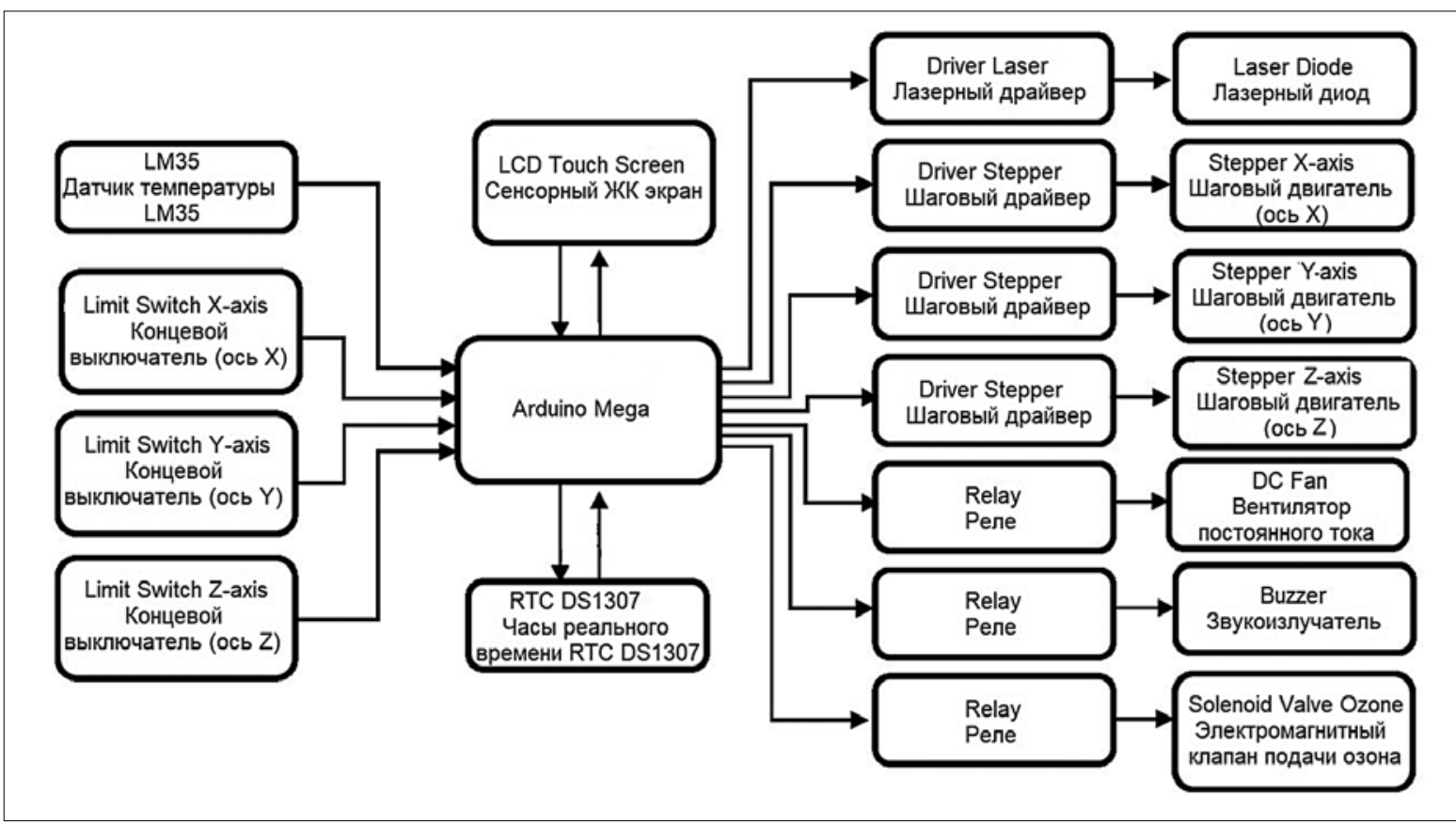

Fig. 1. Apparatus set-up of light and ozone source (a) and microcontroller block diagram (b)

Рис. 1. Схема источника света и озона (a) и блоковая диаграмма микроконтроллера (b) 


\section{Table 1}

Design of sample treatments to reduce S. aureus biofilm

Таблица 1

Типы воздействия на образцы с целью уменьшения биопленок S. aureus

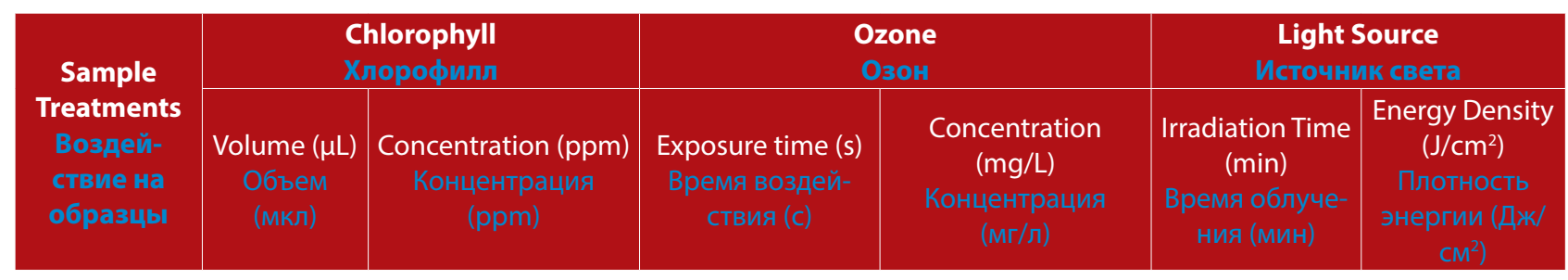

\begin{tabular}{|c|c|c|c|c|c|c|}
\hline $\begin{array}{c}\text { Chlo } \\
\text { Хлорофилл }\end{array}$ & 20 & 1.6 & - & - & - & - \\
\hline \multirow{3}{*}{$\begin{array}{c}\text { Ozone } \\
\text { Озон }\end{array}$} & - & - & 20 & $3 \times 10^{-3}$ & - & - \\
\hline & - & - & 40 & $5 \times 10^{-3}$ & - & - \\
\hline & - & - & 60 & $1 \times 10^{-2}$ & - & - \\
\hline \multirow{5}{*}{$\begin{array}{l}\text { Laser } \\
\text { Лазер }\end{array}$} & - & - & - & - & 1 & 4.35 \\
\hline & - & - & - & - & 2 & 8.69 \\
\hline & - & - & - & - & 3 & 13.04 \\
\hline & - & - & - & - & 4 & 17.39 \\
\hline & - & - & - & - & 5 & 21.74 \\
\hline
\end{tabular}

The apparatus consists of a controller and laser module. The laser diode was previously characterized as having $\lambda=399.81 \pm 15.11 \mathrm{~nm}$ and $P_{\text {out }}=30.43 \mathrm{~mW}$. The control box consists of microcontroller and LCD for setting the constant output intensity and time duration of the laser and controlling the position of the sample holder. The laser module consists of laser diode and sample holders.

All parameters were controlled as shown in Fig. $1 b$. The position of laser diode was controlled according of 96-well microplate position. The experimental treatment was performed in the dark room at $\sim 27^{\circ} \mathrm{C}$.

\section{Ozone Sources}

According to the manufacturer, the ozone source has the output of $400 \mathrm{mg} /$ hours. The time duration of ozone output was controlled and displayed on the LCD. The ozonising probe was aimed directly at the sample. The measurement of $\mathrm{O}_{3}$ molecule concentration added on each time exposure was carried out using the iodometric titration method.

\section{Experimental Design}

Treatment were divided into the following groups: Chlo, Laser, Chlo+Laser, Ozone, Ozone+Laser, Chlo+Ozone+Laser, as shown in Table 1. The concentration of the chlorophyll (1.6 ppm) was based on its toxicity level. According to the described experimental groups, $0.1 \mathrm{ml}$ of the $S$. aureus suspension was added to each well of sterile 96-well flat-bottom microtiter plates with lids. After the biofilm grew, $20 \mu$ lof the chlorophyll was added to the samples, which were then exposed to ozone and irradiated by laser diode at varying exposure time. Irra- diation was done at a distance of $1 \mathrm{~cm}$ apart in a completely dark room. The growth of bacteria in the culture was monitored by measuring OD at $595 \mathrm{~nm}$.

\section{Statistical Analysis}

The data measured in OD was converted to log CFU/ $\mathrm{mL}$ by using Mc. Farland standard diagram with an equation of $(\log \mathrm{CFU} / \mathrm{ml})=3.771+12.374 \times(\mathrm{OD})$. The biofilm reduction was measured using equation 1 [12].

$\%$ Biofilm reduction $=\frac{\left(\sum \text { control }-\sum \text { treatment }\right)}{\sum \text { control }} \times 100 \%$ (1)

For each treatment, the biofilm reduction percentage was calculated based on the control group with the untreated biofilm of $S$. aureus. The results of biofilm reduction were analyzed statistically by ANOVA test with a significance value of $p=0.05$ using IBM SPSS Statistics Version 21.

\section{Results}

\section{Characterization of Chlorophyll sensitizer}

The result of pigment compounds of $D$. angustifolia leaves using thin layer chromatography was shown in Table 2. The Retention factor $\left(R_{f}\right)$ is useful for finding out pigment compound during separation of pigment. The best ratio of the solvent system to get a form of pigments (without beta-carotene) on $D$. angustifolia leaves was petroleum ether and $96 \%$ acetone (8:2), respectively. The $R_{f}$ has a valid value ranging from 0.2 to 1 which shows molecular polarity. Pigments of Chlorophyll-a obtained from $D$. angustifolia leaves extract showed $0.24 R_{f}$ value thus had low polarity. 
Table 2

Result of thin layer chromatography of D. angustifolia leaves extract

Таблица 2

Результат тонкослойной хроматографии экстракта листьев D. Angustifolia

\begin{tabular}{|c|c|c|c|c|c|}
\hline \multirow[b]{2}{*}{$\begin{array}{l}\text { Fraction (color) } \\
\text { (1)акция (цвет) }\end{array}$} & \multicolumn{4}{|c|}{$\begin{array}{c}\text { Retention factor }\left(\mathbf{R}_{\mathbf{f}}\right) \\
\text { Фактор удерживания }\left(\mathbf{R}_{f}\right)\end{array}$} & \multirow[b]{2}{*}{$\begin{array}{l}\text { Pigments } \\
\text { Пигменты }\end{array}$} \\
\hline & $\begin{array}{c}\text { Solvent } \\
\text { PE*: acetone } \\
\text { Растворитель } \\
\text { РЕ*:ацетон (8:2) }\end{array}$ & $\begin{array}{c}\text { Solvent } \\
\text { PE*: acetone } \\
\text { Растворитель } \\
\text { РЕ*:ацетон }(9: 1)\end{array}$ & $\begin{array}{c}\text { Solvent } \\
\text { PE*: acetone } \\
\text { Растворитель } \\
\text { РЕ*:ацетон }(8.5: 1.5)\end{array}$ & $\begin{array}{c}\text { Solvent } \\
\text { PE*: acetone } \\
\text { Растворитель } \\
\text { РЕ*:ацетон }(8: 2)\end{array}$ & \\
\hline $\begin{array}{l}\text { Yellow } \\
\text { Желтый }\end{array}$ & 1 & - & - & - & $\begin{array}{l}\text { Beta-carotene } \\
\text { Бета-каротин }\end{array}$ \\
\hline $\begin{array}{c}\text { Gray } \\
\text { Серый }\end{array}$ & 0.6039 & 0.1625 & 0.4875 & 0.6041 & $\begin{array}{c}\text { Pheophytin a } \\
\text { Феофитин а }\end{array}$ \\
\hline $\begin{array}{c}\text { Yellow brown } \\
\text { Желто-коричневый }\end{array}$ & 0.4950 & 0.0875 & 0.3125 & 0.50 & $\begin{array}{c}\text { Pheophytin b } \\
\text { Феофитин b }\end{array}$ \\
\hline $\begin{array}{c}\text { Blue green } \\
\text { Сине-зеленый }\end{array}$ & 0.2476 & - & 0.15 & 0.2375 & $\begin{array}{l}\text { Chlorophyll a } \\
\text { Хлорофилл а }\end{array}$ \\
\hline $\begin{array}{c}\text { Yellow green } \\
\text { Желто-зеленый }\end{array}$ & 0.1818 & - & 0.0875 & 0.175 & $\begin{array}{l}\text { Chlorophyll b } \\
\text { Хлорофилл b }\end{array}$ \\
\hline
\end{tabular}

Based on Fig. 2, three Gaussian-like peaks with wavelengths of $414 \mathrm{~nm}, 458 \mathrm{~nm}$, and $670 \mathrm{~nm}$ were obtained from the absorption spectrum of the $D$. angustifolia leaves extract. The maximum absorption is at $414 \mathrm{~nm}$ with FWHM of $40.40 \pm 5.27 \mathrm{~nm}$. This result would be used to determine the light source.

\section{Efficacy of Treatment}

The experimental results of the laser group are shown in Fig. 3. The comparison between the control group and chlo group had no significant difference. The Laser group at 2 min of irradiation time showed $13.06 \log \mathrm{CFU} / \mathrm{ml}$ or $57.19 \%$ biofilm reduction while the Chlo+Laser group at 3 min showed about $12.30 \log$ CFU/ml or $59.69 \%$ biofilm

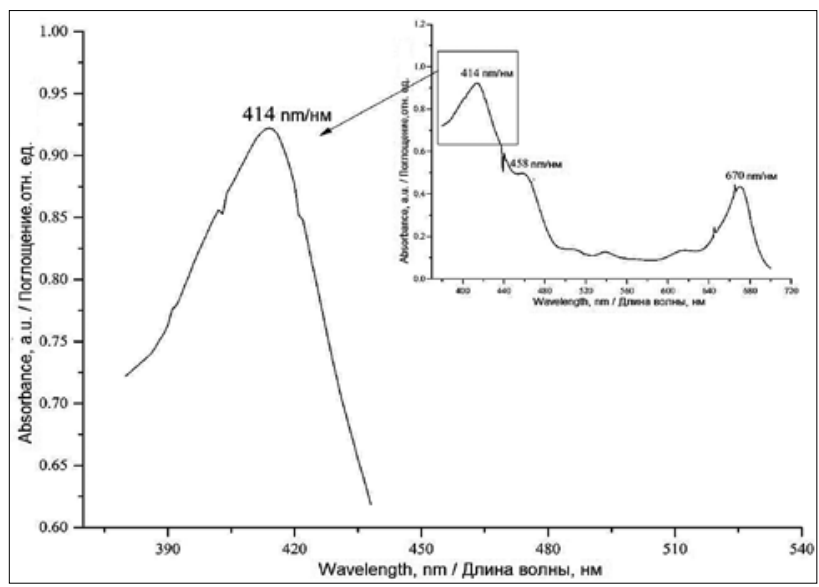

Fig. 2. The absorption spectrum of the Dracaena angustifolia leaves extract

Pис. 2. Спектр поглощения экстракта листьев Dracaena angustifolia reduction. However, the statistical analysis also showed there was no significant difference between both irradiation times indicated by the significance value of $p>0.05$.

Treatment with the Ozone+Laser group (Fig. 4) showed that ozone exposure provides higher biofilm reduction efficacy within $40 \mathrm{~s}$ of exposure time. If laser irradiation was applied, they show the same pattern for each time of irradiation. The ozone group compared with the Ozone+Laser group at $40 \mathrm{~s}$ ozone exposure had significant difference with 20 and 60 s. 40 s of ozone treatment and 4 minutes of laser exposure produced around $11.98 \log \mathrm{CFU} / \mathrm{mL}$ or $60.75 \%$ biofilm reduction.

The result of the Ozone treatment combined with Laser and chlorophyll was shown in Fig. 5. Chlo+Ozone group had no significant difference at any exposure time. The Ozone and Chlo+Ozone treatment groups also had no significant difference. The Chlo+Ozone+Laser group at $20 \mathrm{~s}$ exposure to ozone with 4 min of irradiation time gave $6.02 \log C F U / \mathrm{mL}$ or $80.26 \%$ biofilm reduction and that was the highest biofilm reduction efficacy of all treatment groups.

\section{Discussions}

In photosynthesis, chlorophyll is an important pigment. Chlorophyll-a directly harvests light and transfers energy to reaction center on the photosynthetic system. The solvent system of chlorophyll extraction is an important factor in obtaining the separated fraction of pigment group. This study used petroleum ether (PE) and $96 \%$ acetone as the solvent system for chlorophyll extraction [17]. Retention factor value ranged from 0.2 


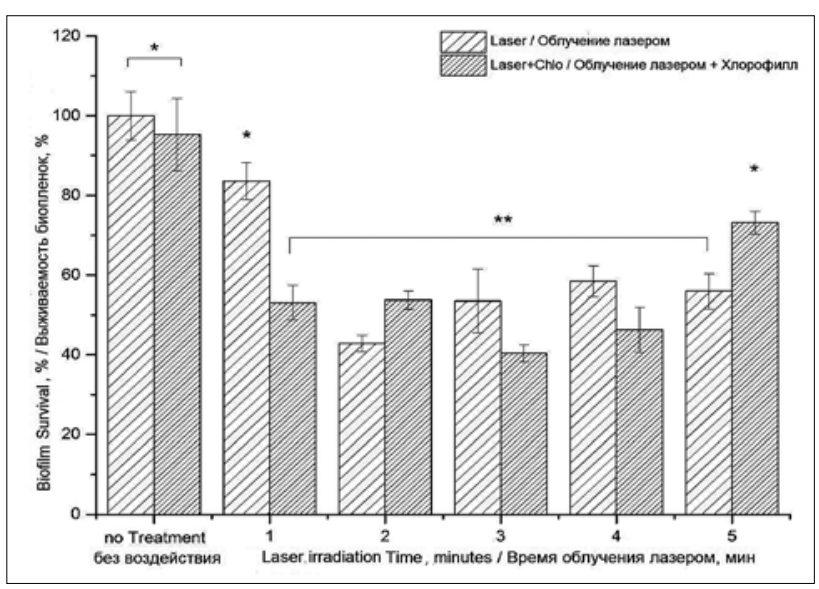

Fig. 3. The experimental results of the Laser group. Symbols * and ${ }^{* *}$ show the significance level of $p<0.05$ and $p>0.05$, respectively Рис. 3. Экспериментальные результаты по группе образцов с лазерным воздействием. Символы ${ }^{*}$ и ${ }^{* *}$ указывают на уровень значимости $p<0,05$ и $p>0,05$, соответственно

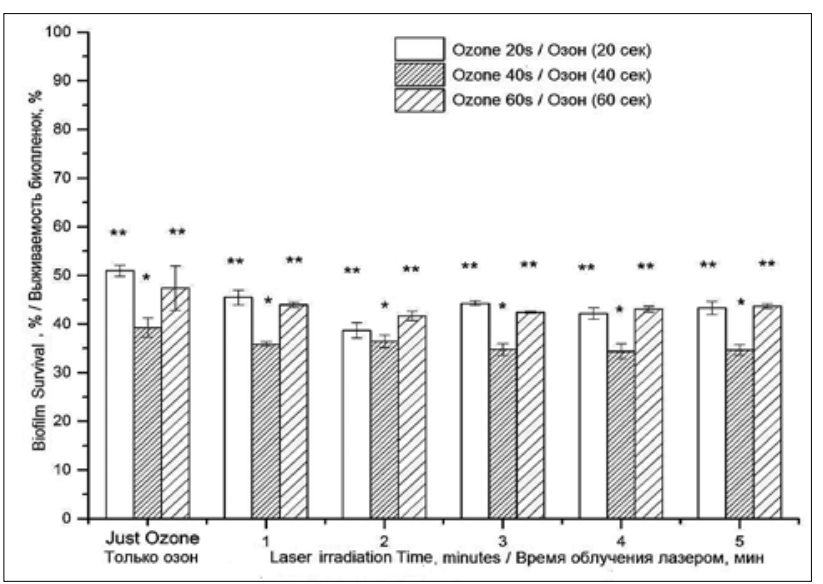

Fig. 4. Treatment results in the ozone and Laser groups. Symbol * and $* *$ show the significance level of $p<0.05$ and $p>0.05$, respectively

Рис. 4. Результаты в группах образцов с воздействием озоном и лазером. Символы * и ** указывают на уровень значимости $\mathrm{p}<0,05$ и $\mathrm{p}>0,05$, соответственно

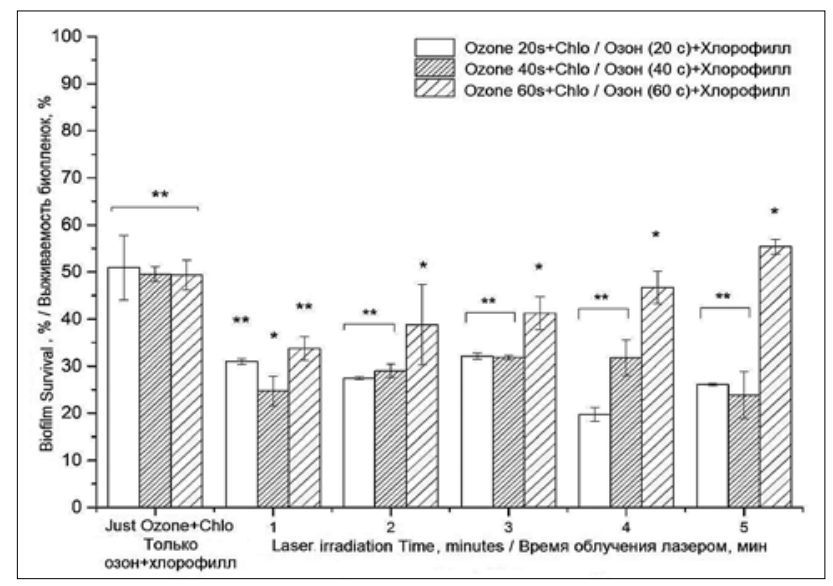

Fig. 5. The result of the Ozone treatment to be applied with Laser the addition of chlorophyll. Symbol $*$ and $* *$ showed the significance level of $p<0.05$ and $p>0.05$, respectively

Рис. 5. Результаты в группах образцов под воздействием озоном и лазером с добавлением хлорофилла. Символы * и ** указывают на уровень значимости $p<0,05$ и p $>0,05$, соответственно to 1. PE and acetone (8:2) solvent had $R_{f}$ of chlorophylla 0.25 , but these contained beta-carotene pigment or carotenoid derivatives. The pigment acts as a protector against damage caused by ROS formation so that chlorophyll extraction had to be made without beta-carotene pigment. The absorbance spectrum of chlorophyll always has three peaks [18]. Chlorophyll extract had an absorption maximum at $414 \mathrm{~nm}$, well correlated with peak wavelength of light source at $\lambda=399.81 \pm 15.11 \mathrm{~nm}$.

The interaction of light and photosensitizer can produce toxic molecules. The photosensitizer in the body has an absorption spectrum that could be elucidated through an optical window that has optical absorption and scattering properties [19-20]. One of the endogen photosensitizers is porphyrin which has various types and absorbance spectra [21]. In previous study, the porphyrin derivatives of $S$. aureus bacteria have a wide peak absorption spectrum and maximum wavelength in blue region $[13,22]$. The other study resulted in the PDT provide an increase in biofilm reduction with the addition of chlorophyll. The dose of light exposure, certain photosensitizer and oxygen play an important role in the success of the PDI $[9,23]$.

The combination of 3 treatments with high exposure to ozone should lead to reduction in survival. However, we finally realized that higher ozone concentration would increase generation of $\mathrm{H}_{2} \mathrm{O}_{2}$, whereas an organism (including animal, plant, and microbe) contains a protein that degrades $\mathrm{H}_{2} \mathrm{O}_{2}$ to oxygen and water. Based on the reaction (Table 3), hydrogen peroxide can bind with other hydrogen peroxide and form non-toxic molecules. Mishra explains that some hydrogen peroxide changes into nontoxic molecules before reaching the cell [24]. So, the point to increasing biofilm reduction is in the density of laser diode, chlorophyll and lower ozone concentrations.

Based on Table 3, the mechanism of Chlo+Laser group could generate of ROS (type II) and free radicals (type I). Photochemical type I reaction occurs when radical anions or cations are formed due to the transfer of electrons (or protons) to oxygen molecules and produce ROS because they easily react with the molecular oxygen. Photochemical type II reaction occurrs when energy is transferred to molecular oxygen to form singlet oxygen [19]. The dominant process depends on the chemical structure and the behavior of photosensitizers.

Treatment with ozone at $40 \mathrm{~s}$ exposure time caused greater reduction of biofilm because $\mathrm{H}_{2} \mathrm{O}_{2}$ are formed [26]. $\mathrm{H}_{2} \mathrm{O}_{2}$ molecules is an oxidant molecule that strengthens immunity by generating free radicals. The generation of free radicals obtained from the oxidative process of electron transfer of $\mathrm{H}_{2} \mathrm{O}_{2}$ through Fenton reaction. Ozone does not penetrate into the tissues but could spread to the cytoplasm [14].

Bocci said that ozone can react and polyunsaturated fatty acids (PUFA), antioxidants, thiol (-SH) compounds, 
Table 3

The mechanisms PDI

Таблица 3

Механизмы фотодинамической инактивации

\begin{tabular}{|c|c|c|}
\hline & $\begin{array}{c}\text { Reactions } \\
\text { Реакции }\end{array}$ & $\begin{array}{l}\text { Ref. } \\
\text { Ссылка }\end{array}$ \\
\hline $\begin{array}{l}\text { Ozone } \\
\mathrm{O} \text { Оон }\end{array}$ & $\mathrm{R}-\mathrm{CH}=\mathrm{CH}-\mathrm{R}^{\prime}+\mathrm{O}_{3}+\mathrm{H}_{2} \mathrm{O} \rightarrow \mathrm{R}-\mathrm{CH}=\mathrm{O}+\mathrm{R}^{\prime}-\mathrm{CH}=\mathrm{O}+\mathrm{H}_{2} \mathrm{O}_{2}$ & [14] \\
\hline $\begin{array}{l}\text { Photophysics } \\
\text { Фотофизика }\end{array}$ & $\begin{array}{c}\mathrm{PS}+\mathrm{hv} \rightarrow{ }^{1} \mathrm{PS}^{*} \\
{ }^{1} \mathrm{PS}^{*} \rightarrow{ }^{3} \mathrm{PS}^{*}\end{array}$ & [25] \\
\hline $\begin{array}{l}\text { Photochemical Type I } \\
\text { Фотохимическая реакция Тип I }\end{array}$ & $\begin{array}{l}{ }^{3} \mathrm{PS}^{*}+{ }^{3} \mathrm{PS}^{*} \rightarrow \mathrm{PS}^{+\cdot}+\mathrm{PS}^{-\cdot} \\
\mathrm{PS}^{-\cdot}+{ }^{3} \mathrm{O}_{2} \rightarrow \mathrm{PS}+{ }^{\cdot-} \mathrm{O}_{2}\end{array}$ & \multirow{2}{*}{ [19] } \\
\hline $\begin{array}{l}\text { Photochemical Type II } \\
\text { Фотохимическая реакция Тип I }\end{array}$ & ${ }^{3} \mathrm{PS}^{*}+{ }^{3} \mathrm{O}_{2} \rightarrow \mathrm{PS}+{ }^{1} \mathrm{O}_{2}$ & \\
\hline $\begin{array}{l}\text { Generation of ozone } \\
\text { Генерация озона }\end{array}$ & $\begin{array}{r}\cdot-\mathrm{O}_{2}+{ }^{\cdot-} \mathrm{O}_{2}+2 \mathrm{H}^{+} \rightarrow{ }^{1} \mathrm{O}_{2}+\mathrm{H}_{2} \mathrm{O}_{2} \\
\mathrm{H}_{2} \mathrm{O}_{2}+\cdot-\mathrm{O}_{2} \rightarrow{ }^{1} \mathrm{O}_{2}+\mathrm{HO}^{\cdot}+\mathrm{OH}^{-} \\
{ }^{1} \mathrm{O}_{2}+\mathrm{H}_{2} \mathrm{O} \rightarrow \mathrm{H}_{2} \mathrm{O}_{3} \stackrel{10_{2}}{\rightarrow} \mathrm{H}_{2} \mathrm{O}_{2}+\mathrm{O}_{3}\end{array}$ & [26] \\
\hline $\begin{array}{l}\text { Catalase } \\
\text { Каталаза }\end{array}$ & $\mathrm{H}_{2} \mathrm{O}_{2}+\mathrm{H}_{2} \mathrm{O}_{2} \rightarrow \mathrm{O}_{2}+2 \mathrm{H}_{2} \mathrm{O}$ & [24] \\
\hline
\end{tabular}

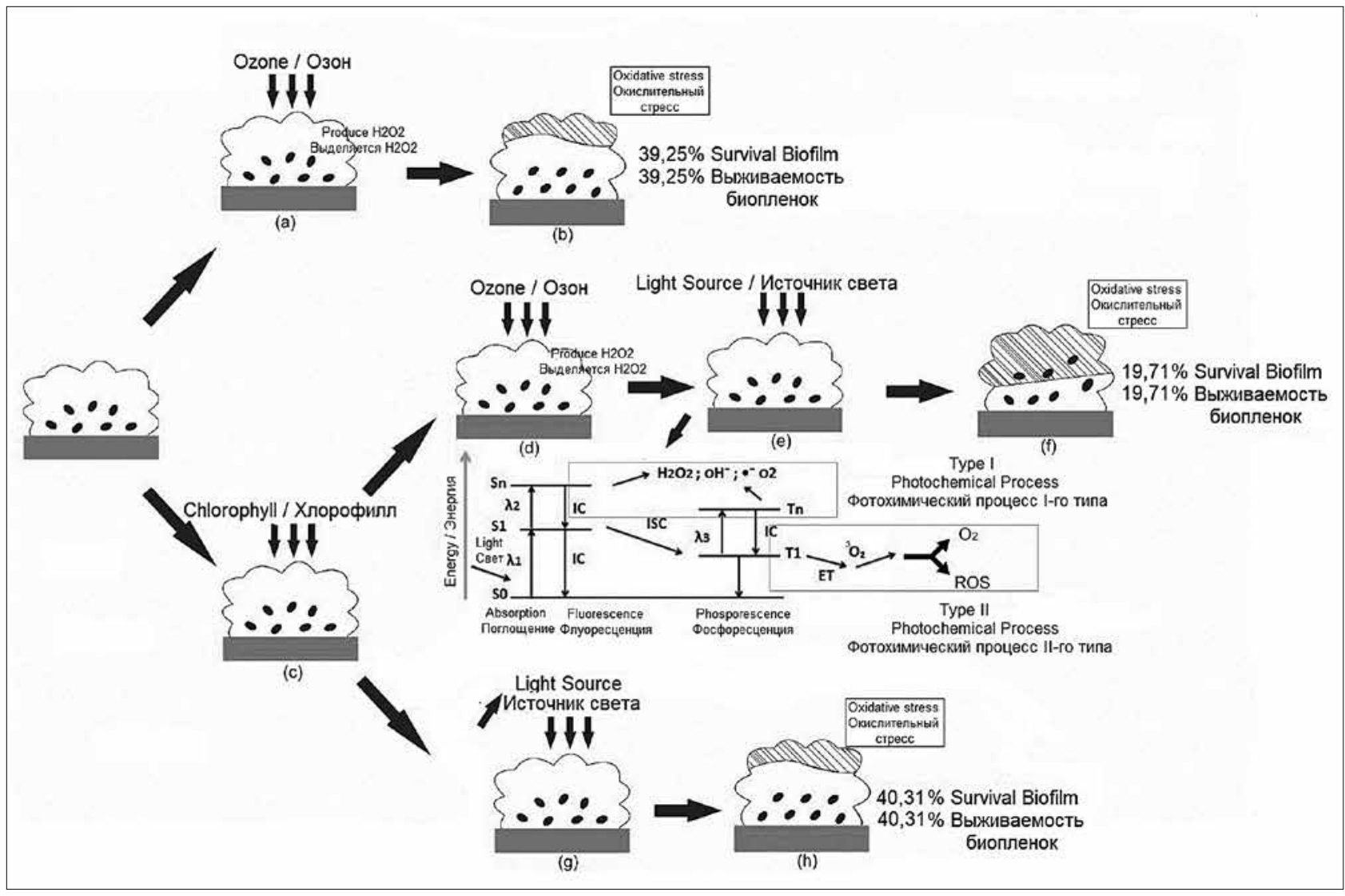

Fig. 6. The mechanisms of PDI treatment: (a) Ozone produces $\mathrm{H}_{2} \mathrm{O}_{2}$ in the biofilm surrounding that diffuses into the cytoplasm; (c) Samples with chlorophyll separated into 2 treatments; (d) Ozone produces a toxic molecule $\left(\mathrm{H}_{2} \mathrm{O}_{2}\right) ;(\mathrm{e})$ and (g) Laser treatment could destroy EPS and increase the amount of toxic molecules through photochemical reaction.

Note: IC: internal conversion, ISC: intersystem crossing, Sn: singlet states, Tn:triplet states, ET: energy transfer; (b), (f), (h) the toxic molecule causes oxidative stress in biofilm

Рис. 6. Механизмы фотодинамической инактивации: (а) Озон производит $\mathrm{H}_{2} \mathrm{O}_{2}$ в окружении биопленки, который диффундирует в цитоплазму; (c) Образцы с хлорофиллом разделены в 2 типа воздействия; (d) Озон производит токсичную молекулу $\left(\mathrm{H}_{2} \mathrm{O}_{2}\right)$; $(\mathrm{e})$ и (g) лазерное воздействие может уничтожить внеклеточный матрикс (EPS) и привести к росту количества токсичных молекул за счет фотохимической реакции.

Примечание: IC: внутренняя конверсия, ISC: межсистемный переход, Sn: синглетные состояния, Tn: триплетные состояния, ET: перенос энергии; (b), (f), (h) токсичная молекула вызывает окислительный стресс в биопленке 


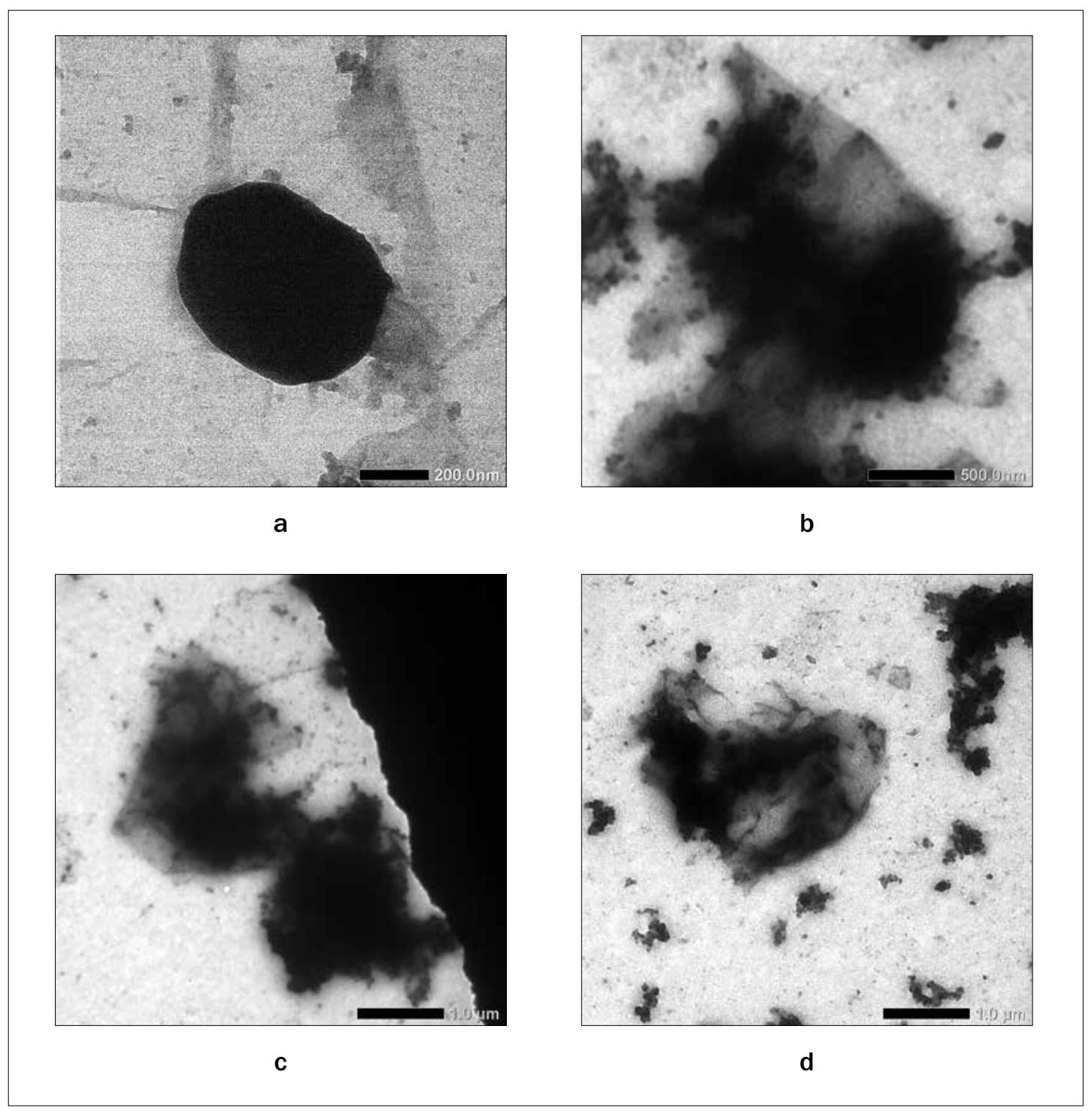

Fig. 7. Microscopic image of Staphylococcus aureus cells treated with laser, chlorophyll and ozone $(\times 100000$ magnification). (a) Normal cell (no treatment), (b) ROS reactions (including singlet oxygen, hydrogen peroxide, and superoxide anion radical) with cell membrane can cause extreme damage, (c) Damage to cell membranes causes the cytoplasm and cell organelles to become partly exposed and react directly with toxic molecules, (d) Cell organelles are directly exposed due to overall loss of the cell membrane

Pис. 7. Микроскопическое изображение клеток Staphylococcus aureus после воздействия лазеров, хлорофиллом и озоном (увеличение $\times 100000)$. (а) Здоровая клетка, (b) Воздействие активных форм кислорода (включая синглетный кислород, перекись водорода и супероксидный анионный радикал) на клеточную мембрану может привести к значительным повреждениям, (c) Повреждение клеточной мембраны частично приводит к непосредственному взаимодействию с токсичными молекулами, (d) Клеточные органеллы полностью открыты ввиду потери клеточной мембраны

glutathione (GSH) and albumin. Inactivation mechanisms occur when some nanoparticles diffuse into biofilm, bind to thiol (-SH) protein species because of high affinity and are affected by denaturation. The enzymes, carbohydrates, DNA and RNA could be affected depending on the ozone dose [14].

In comparison with ozone, the Ozone+Chlo group was not significantly different. There are no interactions between ozone and chlorophyll. Chlo+Ozone+Laser treatment gave higher biofilm reduction efficacy in contrast with ozone group or Ozone+Chlo group. It is fasci- nating to find out that particular treatment of chlorophyll and ozone concentration could enhance efficacy on PDI.

The mechanism of Chlo+Ozone+Laser group generates more toxic compounds to induce cellular damage. Onyango showed the reaction of that component could form toxic compound and generate ozone. Furthermore, the cytotoxic reactions occur continuously in this treatment. Therefore, we need to control the ozone dose for controlling the cytotoxic reaction [27]. Chlo absorbs the energy of laser, causing chlorophyll to be excited. Furthermore, photochemical type II reactions occur, in the 
form of energy transfer from Chlo excited triplets to triplet oxygen. It is acknowledged that because of interaction between photosensitizer and light (Fig. 6), the superoxide anion $\left({ }^{-} \mathrm{O}_{2}\right)$ and singlet oxygen $\left({ }^{1} \mathrm{O}_{2}\right)$ are formed. Each chlorophyll molecule produces approximately $10^{3}-10^{5}$ singlet oxygen molecules before degrading due to photo bleaching or other processes [28]. The production of excess ROS can eliminate biofilms as protectors and cause oxidative stress of bacteria in biofilms.

Based on Fig. 7, the mechanism of cell destruction are due to generation of ROS including singlet oxygen, hydrogen peroxide, and superoxide anion radical. The normal cell of Staphylococcus aureus is a coccus and has slippery surface (Fig. 7a). After treatment, the normal cell has various damage starting from cell membrane. It causes the cytoplasm and cell organelles to react directly with toxic molecules. Grisham used the fluorescent

\section{ЛИТЕРАТУРА}

1. Donlan R.M. Biofilms and Device-Associated Infections // Emerg. Infect. Dis. - 2001. - Vol. 7(2). - P. 277-281.

2. Gordon R.J., Lowy F.D. Pathogenesis of Methicillin-Resistant Staphylococcus aureus Infection // Clin. Infect. Dis. - 2008. - Vol. 46(5). - P. 350-359.

3. Stewart P.S., Costerton J.W. Antibiotic resistance of bacteria in biofilms // Lancet. - 2001. - Vol. 358(9276). - P. 135-138.

4. Oli A.K., Raju S., Nagaveni S. Biofilm formation by Multidrug resistant Enterococcus faecalis (MDEF) originated from clinical samples Ella foundations Hyderabad // J. Microbiol. Biotechnol. Res. - 2012. - Vol. 2(2). - P. 284-288.

5. Xu Y., Itzek A., Kreth J. Comparison of genes required for $\mathrm{H}_{2} \mathrm{O}_{2}$ resistance in Streptococcus gordonii and Streptococcus sanguinis // Microbiology. - 2014. - Vol. 160. - P. 2627-2638.

6. Huang L., Dai T., Hamblin M.R. Antimicrobial Photodynamic Inactivation and Photodynamic Therapy for Infections // Methods Mol Biol. - 2010. - P. 1-18.

7. Castano A.P., Demidova T.N., Hamblin M.R. Mechanisms in photodynamic therapy: part one-photosensitizers, photochemistry and cellular localization // Photodiagnosis and Photodynamic Therapy. - 2004. - Vol. 1(4). - P. 279-293.

8. Astuti S.D., Puspita P.S., Putra A.P., et al. The Antifungal Agent of Silver Nanoparticles Activated by Diode Laser as Light Source to Reduce C. albicans Biofilms: An In vitro Study // Lasers Med. Sci. 2018. doi: 10.1007/s10103-018-2677-4

9. Street C.N., Pedigo L.A., Loebel N.G. Energy Dose Parameters Affect Antimicrobial Photodynamic Therapy-Mediated Eradication of Periopathogenic Biofilm and Planktonic Cultures // Photomed. Laser Surg. - 2010. - Vol. 28(S1). - P. 61-66.

10. Brandis A.S., Salomon Y., Scherz A. Chlorophyll Sensitizers in Photodynamic Therapy // Chlorophylls bacteriochlorophyls: Biochem. Biophys. Funct. Appl. - 2006. - P. 461-483.

11. Song B.H., Lee D.H., Kim B.C., et al. Photodynamic therapy using chlorophyll-a in the treatment of acne vulgaris: A randomized, single-blind, split-face study // J. Am. Dermatology. - 2014. - Vol. 71(4). - P. 764-771.

12. Gomaa I., Ali S.E., El-Tayeb T.A., Abdel-Kader M.H. Chlorophyll derivative mediated PDT versus methotrexate: an in vitro study using MCF-7 cells // Photodiagnosis Photodyn. Ther. - 2012. - Vol. 9(4). - P. 362-368. method to detect $\mathrm{H}_{2} \mathrm{O}_{2}$ formation in the nucleus, mitochondria, endoplasmic reticulum and plasma membrane [29].

\section{Conclusion}

Combination of Chlo+Ozone+Laser treatment with high ozone exposure reduces biofilms by lesser amount. In this study, 3 treatment combinations at 20 s exposure to ozone showed increased biofilm reduction on average. Therefore, it is recommended to use a combination of laser, chlorophyll and lower ozone concentrations to increase the effectiveness of photodynamic inactivation.

We would like to express our gratitude to Directorate General Higher Education (DGHE) of Indonesia for financial support in this research with number 43 / E / KPT / 2017.

\section{REFERENCES}

1. Donlan R.M. Biofilms and Device-Associated Infections, Emerg. Infect. Dis., 2001, vol. 7(2), pp. 277-281.

2. Gordon R.J., Lowy F.D. Pathogenesis of Methicillin-Resistant Staphylococcus aureus Infection, Clin. Infect. Dis., 2008, vol. 46(5), pp. 350-359.

3. Stewart P.S., Costerton J.W. Antibiotic resistance of bacteria in biofilms, Lancet, 2001, vol. 358(9276), pp. 135-138.

4. Oli A.K., Raju S., Nagaveni S. Biofilm formation by Multidrug resistant Enterococcus faecalis (MDEF) originated from clinical samples Ella foundations Hyderabad, J. Microbiol. Biotechnol. Res., 2012, vol. 2(2), pp. 284-288.

5. Xu Y., Itzek A., Kreth J. Comparison of genes required for $\mathrm{H}_{2} \mathrm{O}_{2}$ resistance in Streptococcus gordonii and Streptococcus sanguinis, Microbiology, 2014, vol. 160, pp. 2627-2638.

6. Huang L., Dai T., Hamblin M.R. Antimicrobial Photodynamic Inactivation and Photodynamic Therapy for Infections, Methods Mol Biol, 2010, pp. 1-18.

7. Castano A.P., Demidova T.N., Hamblin M.R. Mechanisms in photodynamic therapy: part one-photosensitizers, photochemistry and cellular localization, Photodiagnosis and Photodynamic Therapy, 2004, vol. 1(4), pp. 279-293.

8. Astuti S.D., Puspita P.S., Putra A.P., Zaidan A.H., Fahmi M.Z., Syahrom A., Suhariningsih. The Antifungal Agent of Silver Nanoparticles Activated by Diode Laser as Light Source to Reduce C. albicans Biofilms: An In vitro Study, Lasers Med. Sci., 2018. doi: 10.1007/s10103-018-2677-4

9. Street C.N., Pedigo L.A., Loebel N.G. Energy Dose Parameters Affect Antimicrobial Photodynamic Therapy-Mediated Eradication of Periopathogenic Biofilm and Planktonic Cultures, Photomed. Laser Surg., 2010, vol. 28(S1), pp. 61-66.

10. Brandis A.S., Salomon Y., Scherz A. Chlorophyll Sensitizers in Photodynamic Therapy, Chlorophylls bacteriochlorophyls Biochem. Biophys. Funct. Appl., 2006, pp. 461-483.

11. Song B.H., Lee D.H., Kim B.C., Ku S.H., Park E.J., Kwon I.H., Kim K.H., Kim K.J. Photodynamic therapy using chlorophyll-a in the treatment of acne vulgaris: A randomized, single-blind, split-face study, J. Am. Dermatology, 2014, vol. 71(4), pp. 764-771.

12. Gomaa I., Ali S.E., El-Tayeb T.A., Abdel-Kader M.H. Chlorophyll derivative mediated PDT versus methotrexate: an in vitro study using MCF-7 cells, Photodiagnosis Photodyn. Ther., 2012, vol. 9(4), pp. 362-368. 
13. Astuti S.D., Arifianto D., Drantantiyas N.D.G., et al. Efficacy of CNCLaser diode Combine with Chlorophylls to Eliminate Staphylococcus aureus Biofilm // IEEE. - 2016. - P. 57-61.

14. Bocci V., Borrelli E., Travagli V., Zanardi I. The Ozone Paradox: Ozone Is a Strong Oxidant as Well as a Medical Drug // Wiley Interscience. -2006.

15. Hegge A.B., Bruzell E., Kristensen S., Tonnesen H.H. Photoinactivation of Staphylococcus epidermidis biofilms and suspensions by the hydrophobic photosensitizer curcumin - Effect of selected nanocarrier: Studies on curcumin and curcuminoides XLVII // Eur. J. Pharm. Sci. - 2012. - Vol. 47(1). - P. 65-74.

16. Milenković S.M., Zvezdanović J.B., Anđelković T.D. The Identification of Chlorophyll and Its Derivatives in The Pigment Mixtures: Hplc-Chromatography, Visible and Mass Spectroscopy Studies // Advanced technologies. - 2012. - Vol. 1(1). - P. 16-24.

17. Torres P.B., Chow F., Furlan C.M., Mandelli F. Standardization of A Protocol to Extract and Analyze Chlorophyll A and Carotenoids // Brazilian J. Oceanogr. - 2014. - Vol. 62(1). - P. 57-63.

18. Porra R.J., Thompson W.A., Kriedemann P.E. Determination of accurate extinction coefficients and simultaneous equations for assaying chlorophylls $a$ and $b$ extracted with four different solvents: verification of the concentration of chlorophyll standards by atomic absorption spectroscopy // Biochim. Biophys. Acta. -1989. - Vol. 975. - P. 384-394.

19. Plaetzer K., Krammer B., Berlanda J., et al. Photophysics and photochemistry of photodynamic therapy: Fundamental aspects // Lasers Med. Sci. - 2009. - Vol. 24(2). - P. 259-268.

20. Liu J., Zeng Y., Lin F. Optic Experimental study on light scattering by biological cells with discrete sources method // Opt. - Int. J. Light Electron Opt. - 2016. - Vol. 127(11). - P. 4731-4735.

21. Wainwright M. Photosensitisers in Biomedicine. - $1^{\text {st }}$ Edition Wiley Blackwell, 2009. - P. 13-36.

22. Lipovsky A., Nitzan Y., Friedmann H., Lubart R. Sensitivity of Staphylococcus aureus strains to broadband visible light // Photochem. Photobiol. - 2009. - Vol. 85(1). - P.255-260.

23. Nikitina R.G., Kaplan M.A., Morozova T.G., et al. Role of laser energy density for photodynamic therapy of radiation injuries of the skin // Bull. Exp. Biol. Med. - 2005. - Vol. 140(5). - P. 558-560.

24. Mishra S., Imlay J. Why Do Bacteria Use So Many Enzymes to Scavenge Hydrogen Peroxide? // Arch Biochem Biophys. - 2012. Vol. 525(2). - P.145-160.

25. Weishaupt K.R., Gomer C.J., Dougherty T.J. Identification of Singlet Oxygen as The Cytotoxic Agent in Photo-inactivation of a Murine Tumor // Cancer Res. - 1976. - Vol. 36. - P. 2326-2329.

26. Borrelli E., Bocci V. Basic Biological and Therapeutic Effects of Ozone Therapy in Human Medicine. in Ozone Science and Technology / Encyclopedia of Life Support Systems (EOLSS) [Ed. Rein Munter]. - Oxford: Eolss Publishers, 2010. [Available at: http:// www.eolss.net] [Retrieved June 22, 2018]

27. Onyango A.N. Endogenous Generation of Singlet Oxygen and Ozone in Human and Animal Tissue: Mechanism, Biological Significance, and Influence of Dietary Components // Oxidative Medicine and Cellular Longevity. - 2016. - 22 p. http://dx.doi. org/10.1155/2016/2398573

28. Astuti S.D., Zaidan A., Setiawati E.M., Suhariningsih. Chlorophyll mediated photodynamic inactivation of blue laser on Streptococcus mutans // AIP Conference Proceedings 1718. - 2016. 120001. Available at:http://dx.doi.org/10.1063/1.4943353

29. Grisham M.B. Methods of Detect Hydrogen Peroxide in Living Cells: Possibilities and Pitfalls // Comparative Biochemistry and Physiology. - 2013. - P. 1-10.
13. Astuti S.D., Arifianto D., Drantantiyas N.D.G., Nasution A.M.T. Abdurachman. Efficacy of CNC-Laser diode Combine with Chlorophylls to Eliminate Staphylococcus aureus Biofilm, IEEE, 2016, pp. 57-61.

14. Bocci V., Borrelli E., Travagli V., Zanardi I. The Ozone Paradox: Ozone Is a Strong Oxidant as Well as a Medical Drug, Wiley Interscience, 2006.

15. Hegge A.B., Bruzell E., Kristensen S., Tonnesen H.H. Photoinactivation of Staphylococcus epidermidis biofilms and suspensions by the hydrophobic photosensitizer curcumin - Effect of selected nanocarrier: Studies on curcumin and curcuminoides XLVII, Eur. J. Pharm. Sci., 2012, vol. 47(1), pp. 65-74.

16. Milenković S.M., Zvezdanović J.B., Anđelković T.D. The Identification of Chlorophyll and Its Derivatives in The Pigment Mixtures: Hplc-Chromatography, Visible and Mass Spectroscopy Studies, Advanced technologies, 2012, vol. 1(1), pp. 16-24.

17. Torres P.B., Chow F., Furlan C.M., Mandelli F. Standardization of A Protocol to Extract and Analyze Chlorophyll A and Carotenoids, Brazilian J. Oceanogr., 2014, vol.62(1), pp. 57-63.

18. Porra R.J., Thompson W.A., Kriedemann P.E. Determination of accurate extinction coefficients and simultaneous equations for assaying chlorophylls $a$ and $b$ extracted with four different solvents: verification of the concentration of chlorophyll standards by atomic absorption spectroscopy, Biochim. Biophys. Acta, 1989, vol. 975, pp. 384-394.

19. Plaetzer K., Krammer B., Berlanda J., Berr F., Kiesslich T. Photophysics and photochemistry of photodynamic therapy: Fundamental aspects, Lasers Med. Sci., 2009, vol. 24(2), pp. 259-268.

20. Liu J., Zeng Y., Lin F. Optic Experimental study on light scattering by biological cells with discrete sources method, Opt. - Int. J. Light Electron Opt., 2016, vol. 127(11), pp. 4731-4735.

21. Wainwright M. Photosensitisers in Biomedicine. 1st Edition Wiley Blackwell, 2009. pp. 13-36.

22. Lipovsky A., Nitzan Y., Friedmann H., Lubart R. Sensitivity of Staphylococcus aureus strains to broadband visible light, Photochem. Photobiol., 2009, vol. 85(1), pp. 255-260.

23. Nikitina R.G., Kaplan M.A., Morozova T.G., Drozhzhina V.V., Epatova T.V., Luk'yanova E.Yu. Role of laser energy density for photodynamic therapy of radiation injuries of the skin, Bull. Exp. Biol. Med., 2005, vol. 140(5), pp. 558-560.

24. Mishra S., Imlay J. Why Do Bacteria Use So Many Enzymes to Scavenge Hydrogen Peroxide?, Arch Biochem Biophys., 2012, vol. 525(2), pp. 145-160.

25. Weishaupt K.R., Gomer C.J., Dougherty T.J. Identification of Singlet Oxygen as The Cytotoxic Agent in Photo-inactivation of a Murine Tumor, Cancer Res., 1976, vol. 36, pp. 326-2329

26. Borrelli E., Bocci V. Basic Biological and Therapeutic Effects of Ozone Therapy in Human Medicine. in Ozone Science and Technology] in Encyclopedia of Life Support Systems (EOLSS) by Rein Munter as edt. Oxford, Eolss Publishers, 2010. [Available at: http:// www.eolss.net] [Retrieved June 22, 2018]

27. Onyango A.N. Endogenous Generation of Singlet Oxygen and Ozone in Human and Animal Tissue: Mechanism, Biological Significance, and Influence of Dietary Components, Oxidative Medicine and Cellular Longevity, 2016, 22 p. http://dx.doi. org/10.1155/2016/2398573

28. Astuti, S.D., Zaidan, A., Setiawati, E.M., Suhariningsih, 2016, Chlorophyll mediated photodynamic inactivation of blue laser on Streptococcus mutans, AIP Conference Proceedings 1718, 2016, 120001. http://dx.doi.org/10.1063/1.4943353

29. Grisham M.B. Methods of Detect Hydrogen Peroxide in Living Cells: Possibilities and Pitfalls, Comparative Biochemistry and Physiology, 2013, pp.1-10 